\title{
STUDIES ON CULTURED SCHWANN CELLS: \\ THE INDUCTION OF MYELIN SYNTHESIS, AND THE CONTROL OF THEIR PROLIFERATION BY A NEW GROWTH FACTOR
}

\author{
By J. P. BROCKES, K. J. FRYXELL AND G. E. LEMKE \\ Division of Biology, \\ California Institute of Technology, \\ Pasadena, California 91 I25
}

\section{SUMMARY}

We have recently described the use of immunological methods to identify and purify rat Schwann cells. In dissociated cultures of neonatal sciatic nerve, all of the cells can be identified by antigenic criteria as either Schwann cells or fibroblasts. The fibroblasts may be removed by treatment with antiserum to the Thy-I antigen and complement. The purified Schwann cells have been used to study the regulation of the expression of myelin components, and the stimulation of Schwann cell division by a soluble growth factor.

Among the components of myelin, we have concentrated on the peripheral myelin glycoprotein $\mathrm{P}_{0}$, which constitutes $50-60 \%$ of the protein in peripheral myelin. We have studied the distribution of $\mathrm{P}_{0}$ in vitro and in vivo by immunofluorescence, immuno-autoradiography on SDS gels, and solidphase radioimmunoassay. Our results support the hypothesis that $P_{0}$ is induced specifically as a consequence of the interaction between the Schwann cell and the myelinated type of axon. The level of $\mathrm{P}_{0}$ in the myelin membrane is at least 1000-fold higher than in the Schwann cell membrane.

Purified Schwann cells divide very slowly in a conventional tissue culture medium. This has alowed us to purify a new growth factor from extracts of brain and pituitary, tentatively named Glial Growth Factor (GGF). The activity resides in a basic protein with a native molecular weight of $6 \times 10^{4}$ daltons and a subunit molecular weight of $3 \times 10^{4}$ daltons, which is active at levels comparable to those of epidermal growth factor. GGF is mitogenic for Schwann cells, astrocytes ạnd muscle fibroblasts.

\section{INTRODUCTION}

One important goal for the student of neurone-glial interactions is to understand these phenomena in molecular terms. As a first step, this would require the purification and characterization of those molecules involved in signalling between neurones and glia. While in vivo studies will doubtless continue to be fruitful, it seems likely that studies in vitro will play an increasingly important role in analysing the cellular phenomena and in characterizing the important molecules. It will probably be necessary to study these interactions between purified populations of neurones and - lia whose properties may be studied separately or in co-culture. The derivation 
of such purified populations poses a significant problem, both of identifying particular cell type in vitro, and also of purifying it from the complex mixtures of cells found in the nervous system. Incisive solutions to similar problems have come from cellular immunology - the study of subpopulations of lymphocytes and their interactions in the immune response. These subpopulations are defined by antisera which recognize cell type-specific surface antigens. Immunologists have developed methods for the derivation, assay and use of these antisera to identify and purify lymphocytes (for a recent practical account, see Mishell \& Shiigi, I980). This methodology has been revolutionized in recent years by procedures for the derivation of monoclonal antibodies. Such approaches are becoming increasingly important in cellular neurobiology.

These issues are exemplified in this paper by a consideration of studies on the Schwann cell, with emphasis on work performed in this laboratory. We describe the application of immunological methods to derive pure populations of Schwann cells; and the use of such populations to study the interaction that leads to myelin formation and the control of Schwann cell proliferation in vitro. In these latter experiments the purified cells have allowed the definition of a new growth factor/ hormone, found in the brain and pituitary, which may be important for the control of cell division during development and regeneration.

IMMUNOLOGICAL IDENTIFICATION OF RAT SCHWANN CELLS IN TITTRO

In dissociated cultures of the neonatal rat sciatic nerve, all of the cells can be identified as either Schwann cells or fibroblasts of the nerve connective tissue, by virtue of their reaction with two antisera to cell surface antigens (Brockes, Fields \& Raff, 1977). The Schwann cells, but not the fibroblasts, are positive for the Ran-I antigen, originally defined by a mouse antiserum made against a rat glial tumour cell line called 33 B (Fields et al. 1975). After absorption with non-neural cells, the antiserum reacts with Ran-I, an antigen with a very restricted distribution in the normal nervous system, which has thus far been identified on all rat Schwann cells (Brockes et al. 1977; Fields et al. 1978) and a minor population of cells in the leptomeninges (Raff et al. 1979). The fibroblasts, but not the Schwann cells, carry the well characterized Thy-I antigen, originally defined by murine alloantisera. Thy-I is a surface glycoprotein which is present in various inbred mouse strains as either the Thy $I \cdot I$ or Thy I'2 allotypes (Reif \& Allen, I966). It is found on a variety of cell types in the mouse, including T lymphocytes (Raff, 1969), myoblasts (Lesley \& Lennon, 1977), epithelial cells (Scheid et al. 1972) and fibroblasts (Stern, 1973). A similar molecule is present on rat cells. All rat strains apparently react with alloantisera against the mouse Thy I I determinants (Douglas, I 972). The non-overlapping distribution of these two antigens on cells in the sciatic nerve cultures was established with a double label immunofluorescence assay which unambiguously identifies all

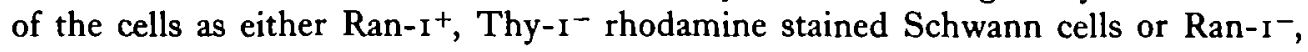
Thy- I $^{+}$fluorescein stained fibroblasts (Brockes et al. 1977).

In addition, all of the Ran-I ${ }^{+}$Schwann cells also express in their cytoplasm th 
heuroectodermal Sroo antigen, which is not detectable in the fibroblasts (Brockes, Fields \& Raff, 1979). All of the Thy- ${ }^{+}$fibroblasts, however, express the extracellular fibronectin (LETS protein) antigen which is not found on the Schwann cells. These cultures are thus the simplest possible example of cellular heterogeneity.

It should be stressed that morphology alone is not a sufficiently rigorous criterion for identifying the Schwann cell. Although many of these cells have a characteristic bipolar morphology, they readily undergo a reversible morphological transition to a flattened form that is indistinguishable from a flbroblast (Brockes et al. 1977). The flattened form, however, has the Ran-I+ $\mathrm{S}_{10} 0^{+}$Thy-I- LETS- ${ }^{-}$phenotype and is thus identifiable as a Schwann cell. A variety of marker antigens are now available (see chapters by Akeson, Fields \& Schachner in Friedlander, 1979) for the major classes of neurones and glia, and also for subsets of neurones and glia (Reichardt, Raff \& McKay, 1981). These antigens could be used to derive purified populations of cells either by positive selection - for example, the selective retention of a cell type by an affinity column bearing immobilized antibody, or by negative selection for example, removing unwanted cell types with antibody and complement. The negative selection is technically somewhat easier and works very effectively in the sciatic nerve cultures. It has been relatively straightforward to apply immunological methods for purification of Schwann cells from sciatic nerve cultures; it may be more difficult, however, in cultures with more complex cellular heterogeneity.

\section{ESTABLISHMENT OF PURIFIED POPULATIONS OF SCHWANN CELLS}

In a conventional tissue culture medium containing $10 \%$ foetal calf serum, the rat Schwann cell divides very slowly (Raff et al. $1978 b$; Brockes et al. 1979). It is therefore possible to select against the more rapidly dividing $T h y-\mathrm{I}^{+}$fibroblasts by treating the sciatic nerve cultures with the anti-mitotic reagent cytosine arabinoside (Brockes et al. 1979). A similar procedure has also been used successfully on cultures of the rat dorsal root ganglion (Wood, 1976). The most effective procedure, however, for removing the fibroblasts has been to treat the cells in suspension with antiserum to Thy $I \cdot I$, followed by complement-dependent lysis of Thy- ${ }^{+}$cells. This gives rise to cell populations that are routinely greater than $99.5 \%$ Ran- $I^{+}$Schwann cells, and often greater than $99.9 \%$ (Brockes et al. 1979). The Schwann cells are stimulated to divide by a protein factor present in the brain and pituitary (see below), and this has allowed us to expand the cell population and passage it on several occasions with, if necessary, further treatments with anti-Thy $\mathrm{I} \cdot \mathrm{I}$ and complement. The commercial availability of monoclonal $\operatorname{IgM}$ anti-Thy $I \cdot I$ has made this procedure available to laboratories without expertise in immunology.

There has been considerable interest in the use of neural cell lines to study questions in cellular neurobiology (Pfeiffer et al. 1978). Such studies have often been fruitful, but it is important to realize that cell lines may differ markedly from normal cells. The availability of purified Schwann cells allowed us (Brockes \& Raff, 1979) to compare their properties with those of the well characterized rat Schwann cell lines RN2 and RN22 (Pfeiffer \& Wechsler, 1972). Normal Schwann cells were bund to differ significantly from $\mathrm{RN}_{2}$ and $\mathrm{RN}_{22}$ after various treatments in culture, 
such as the elevation of intracellular cyclic AMP levels, which is mitogenic for Schwann cells (Raff, Hornby-Smith \& Brockes, 1978a) but decreases the growth rate of the cell lines (Brockes \& Raff, 1979). These studies illustrate the need for caution in extrapolating from the cell lines to normal cells of the nervous system.

The use of immunoselective methods has therefore provided a reproducible procedure for deriving pure populations which retain their identity as Schwann cells as evidenced by their continued Ran- ${ }^{+} \mathrm{Sr}_{100^{+}}$phenotype (Brockes, $198 \mathrm{I}$ ). We now describe the utility of these cells for studies on peripheral myelination.

\section{STUDIES ON PERIPHERAL MYELINATION}

The Schwann cell may relate to peripheral nerve axons in one of two ways (for review, see Webster, 1975). Several smaller axons, which remain unmyelinated, may be enclosed by one Schwann cell which envelops them within a single layer of cytoplasm into a nerve bundle. The larger axons are each enclosed by single Schwann cells which line up with intervals (the future nodal region) between them. After enclosing large axons, the plasma membrane of the Schwann cell joins to form a double membrane structure called the mesaxon. The mesaxon then elongates around the axon in a spiral fashion, which generates, after membrane fusion and compaction, the myelin sheath (Geren, 1954). Myelin formation is perhaps the most dramatic example of neurone-glial interaction and one of the most impressive examples of cell-cell interaction.

It is now generally accepted that there is one class of Schwann cell, which may interact with either of two classes of axon - one competent to induce the Schwann cell to myelinate and the other not. For example, if the proximal stump of a myelinated nerve is anastomosed to the distal stump of a non-myelinated nerve, the axons are myelinated as they grow through the stump (Simpson \& Young, 1945; Hillarp \& Olivecrona, 1946). A variety of labelling experiments with tritiated thymidine have provided evidence that the migration of Schwann cells from the proximal stump is not important in this case, and that the cells that divide after nerve injury are able to respond to either class of axon (Weinberg \& Spencer, 1976; Aguayo et al. 1976a; Aguayo, Charron \& Bray, 1976b). It appears therefore that the myelinated type of axon possesses some quality, absent from unmyelinated axons, which triggers the Schwann cell (Spencer \& Weinberg, 1978). It should be emphasized that myelination is a complex process which may involve signalling between both cell types at different stages in the process. Nonetheless, the early events, which determine whether or not myelination will begin, appear to reflect 'recognition' by Schwann cells of axons possessing the requisite quality. We have found, as described below, that this recognition has at least one readily assayable consequence - the induction of the myelin glycoprotein $P_{0}$. This system may in certain respects be more amenable to biochemical analysis than more familiar examples of neuronal recognition, such as synaptogenesis. It is possible, furthermore, that the neuronal molecules mediating synaptogenesis and myelinogenesis may be related, or at least show parallels in their action.

One hypothesis about the axonal quality has been that myelination is simply initiate when a critical axonal diameter is reached (Duncan, 1934; Matthews, 1968). Althoug. 

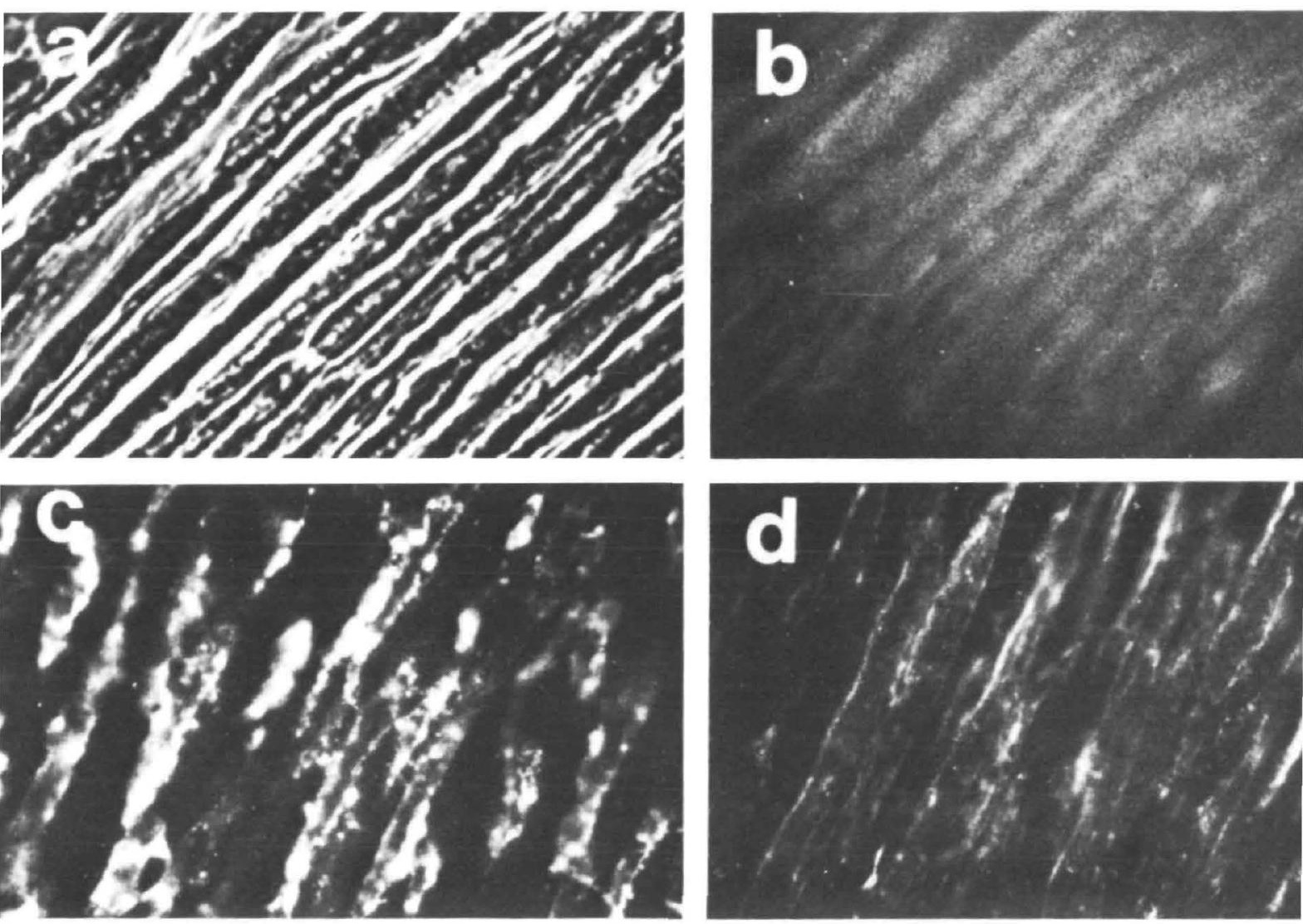

ig. I. Detection of $P_{0}$ and $P_{1}$ in peripheral myelin sheaths by indirect immunofluorescence. Frozen sections ( $4 \mu \mathrm{m}$ thick) at sciatic nerve were viewed by phase contrast $(a)$, and by fluorescence after reaction with pre-immune rabbit serum $(b$ ) nti- $P_{0}$ serum $(c)$ or rabbit anti-PI antıbodies $(d)$ followed by goat anti-rabbit IgG conjugated to rhodamine. Full detail rocedure are given in Brockes et al. (1980a). 

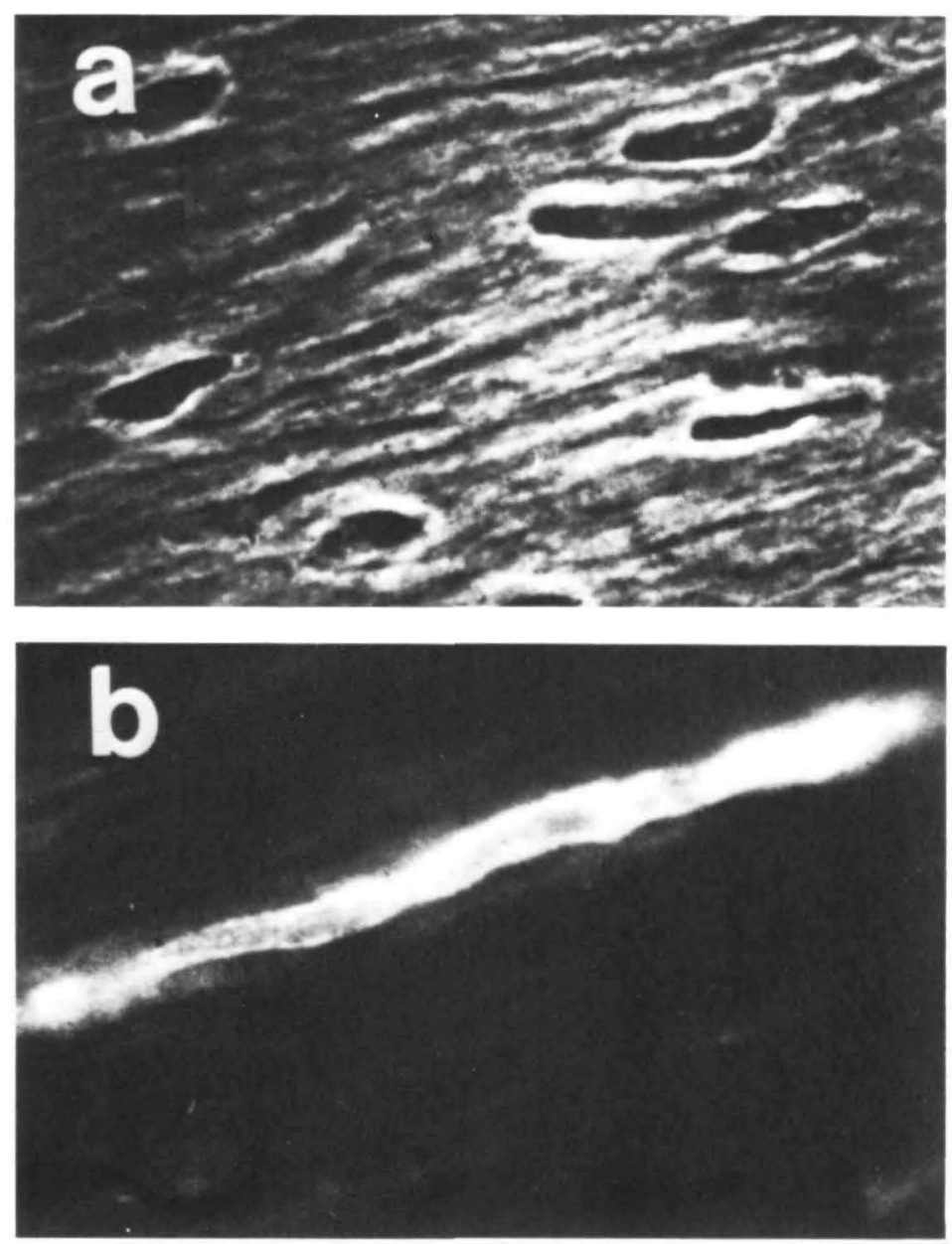

Fig. 2. Detection of $P_{0}$ in the occasional myelinated axon of the cervical sympathetic trunk. A longitudinal frozen section of the CST was viewed by phase contrast $(a)$ and fluorescence (b) after reaction with rabbit anti- $P_{0}$ antiserum followed by goat anti-rabbit $\mathbf{I g G - r h o d a m i n e . ~}$ 
Konal diameter per se may be an important parameter in the process of recognition, it seems unlikely that this can be the only factor since the correlation with initial axon diameter is not absolute (Spencer \& Weinberg, 1978). It has been suggested that a chemical signal is involved in the initiation of myelination; this may reflect some difference in the surface chemistry of the two classes of axon (Spencer \& Weinberg, 1978) or alternatively a factor transported up one class of axon and released to influence the Schwann cell. The idea of a diffusible signal seems less appealing than a contact mediated one because of the intimate association of myelinated and unmyelinated axons in a 'mixed' peripheral nerve. The hypothetical nature of this discussion underlines the fact that although there is considerable information about the chemical composition and ultrastructure of myelin itself, we have little information about the interaction that leads to myelin formation, and none about the molecular basis of this interaction.

One important issue is whether the myelin proteins are normal components of the Schwann cell membrane that are also incorporated into myelin, or whether they are induced specifically as a consequence of the interaction with the myelinated type of axon that was discussed above. A major component of rat peripheral myelin is the $\mathrm{P}_{0}$ glycoprotein which accounts for $50-60 \%$ of the protein in the myelin sheath and has an apparent molecular weight of $28000-30000$ when analysed by SDS gel electrophoresis (Greenfield et al. 1973; Everly, Brady \& Quarles, 1974; Wood \& Dawson, 1974). Although some experiments have been performed with assays for the myelin basic protein, we have chosen to emphasize in this paper our studies on $\mathrm{P}_{\mathbf{0}}$ because it is quantitatively predominant. After immunizing with electrophoretically purified $P_{0}$, we have derived a rabbit antiserum (Brockes et al. $1980 a$ ) that has been used in three different assay procedures. Our results with these assays (summarized in Table $I$ ) strongly support the hypothesis of induction of $P_{0}$ by nerve axons.

The first assay was the immunohistochemical detection of $P_{0}$ by indirect immunofluorescence on frozen sections of tissue from the PNS and CNS (Brockes et al. $1980 a$ ). The antiserum stained the myelin sheath, but not the axon, in adult rat sciatic nerve (Figs. I $a-c$ ) but it did not react detectably with central myelin in the optic nerve or cerebral cortex. Similar results have been obtained by Trapp et al. (1979), who have used a rabbit antiserum to bovine $P_{0}$ in conjunction with the peroxidase-antiperoxidase procedures and also observed labelling that is restricted to the PNS. When we investigated the distribution of $\mathrm{P}_{0}$ on sections of the cervical sympathetic trunk (Fig. $2 a, b$ ), a predominantly unmyelinated nerve, the occasional myelinated axons were detectably stained, whereas the unmyelinated axons were not. In sections of the neonatal sciatic nerve the antiserum gave focal staining of those areas that were presumably beginning to myelinate but was otherwise negative. When live or fixed-cultured Schwann cells were stained after more than 5 days in culture, they were also negative for $\mathrm{P}_{0}$ (Brockes et al. 1980a). After $16-20 \mathrm{~h}$ in culture, however, approximately $8 \%$ of Schwann cells dissociated from neonatal sciatic nerve expressed $\mathrm{P}_{0}$, as detected by immunofluorescence; this declined to $0 \%$ after 4 days in culture (Mirsky et al. 1980 ).

A second assay procedure has been to separate proteins on SDS gels and then detect the binding of anti $P_{0}$ to the gels by an immuno-autoradiographic procedure Aurridge, I980). As shown in Fig. 3, the antiserum reacts with as little as $40 \mathrm{ng}$ 
(a) Pre-immune

(b) Anti $P_{0}$

(c) Stain

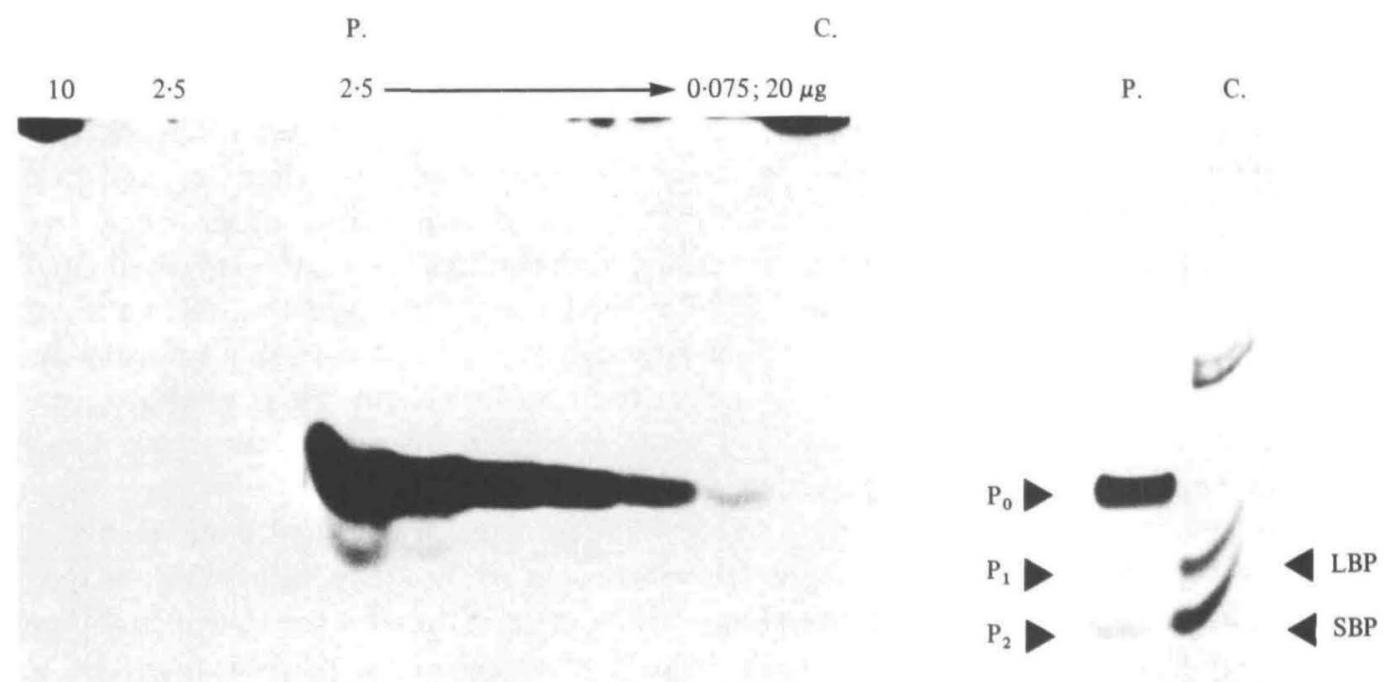

Fig. 3. Immuno-autoradiographic detection of reaction of anti- $P_{0}$ antiserum with SDS gels of purified rat peripheral and central myelin. (a) Reaction with pre-immune serum. Track 1, $10 \mu \mathrm{g}$ central myelin, 2-10 $\mu \mathrm{g}$ peripheral myelin. (b) Reaction with anti- $\mathrm{P}_{0}$. Tracks $1-6$ contain $2.5,1.25,0.6,0.3,0.15,0.075 \mu \mathrm{g}$ of peripheral myelin, 7-20 $\mu \mathrm{g}$ central myelin. (c) Staining with Coomassie blue. Track I, $20 \mu \mathrm{g}$ peripheral myelin; 2-20 $\mu \mathrm{g}$ central myelin. Details of the gels, the reactions with antiserum and [ $\left.{ }^{125} \mathrm{I}\right]$ protein $A$, and the autoradiography are given in Brockes et al. (1980a).

of the 28000 dalton band in peripheral myelin but does not react detectably with $20 \mu \mathrm{g}$ of central myelin, thus supporting the fluorescence results on frozen sections of CNS and PNS. In addition (see Table $\mathrm{I}$ ) this procedure detects $28 \mathrm{~K} \mathrm{P}_{0}$ in extracts of neonatal and adult sciatic nerve, but not in extracts of cultured Schwann cells (cultured more than 5 days) or Schwann-cell membrane fractions (Brockes et al. $1980 a$ ). This assay adds the criterion of molecular weight to the identification of the immunoreactive species but has the disadvantage that it is only a semi-quantitative procedure.

In order to quantitate $P_{0}$ levels more accurately, we have recently developed a sensitive solid-phase radio-immunoassay (RIA) using the rabbit antiserum (Fryxell, Balzer \& Brockes, I98I). In this procedure, plastic microwells are passively coated with peripheral myelin proteins, and then reacted with anti- $\mathrm{P}_{0}$ in the presence of competitor extracts. The bound antibody is quantitated by incubation with [ $\left.{ }^{225} \mathrm{I}\right]-$ Staphylococcus aureus protein A. Fig. 4 shows the standard curve of such an assay, both before and after the logit transform, which we use to linearize the results. We have been able to reliably detect as little as $0.8 \mathrm{ng}$ of $\mathrm{P}_{0}$ using this assay (Fryxell et al. I98I). As shown in Table $I$, extracts of the neonatal sciatic nerve contain approximately $2 \%$ of the level in adult sciatic nerve. Central myelin and central nervous system extracts have less the $0.1 \%$ of the level in peripheral myelin, providing further evidence for the peripheral specificity of $\mathrm{P}_{0}$. Furthermore, cultured Schwann cells, or Schwann cell membranes, also contain less than $0.1 \%$ of the level in periphe myelin (Table I). 
(a)

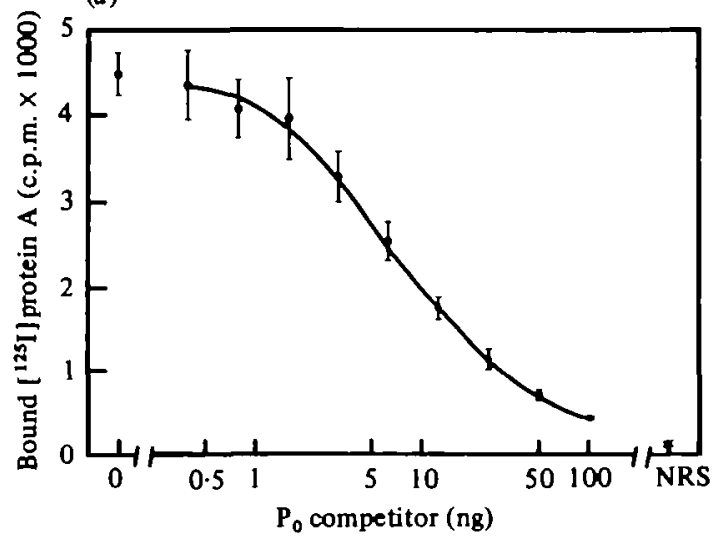

(b)

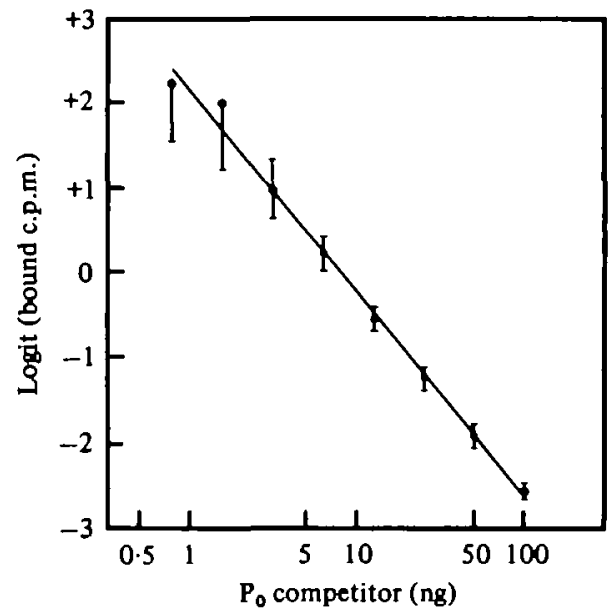

Fig. 4. Solid phase radioimmunoassay of the $P_{0}$ glycoprotein. (a) Standard curve, plotting the cpm [12 I]protein $A$ binding to $P_{0}$-coated microwells, versus the amount of soluble $P_{0}$ competitor on a $\log$ scale. Each point represents the mean \pm standard deviation of 12 determinations. (b) The same data linearized with a logit transformation:

$$
\text { logit } B=\ln \left(\frac{B}{100-B}\right), \text { where } B=\frac{\mathrm{cpm} \text { of sample }-\mathrm{cpm} \text { normal serum }}{\mathrm{cpm} \text { of o competitor }-\mathrm{cpm} \text { normal serum }} .
$$

Each point represents logit (mean cpm); the error bars indicate logit (mean cpm \pm I S.D. cpm). The error bars are not symmetrical because of the mathematics of the logit transform. $A$ detailed account of the assay procedure is given in Fryxell et al. (1981).

In summary, these results provide strong support for the hypothesis that the expression of $\mathrm{P}_{0}$ is induced by interaction with the myelinated type of axon. $\mathrm{P}_{0}$ is not detectable by immunofluorescence in Schwann cells growing in vitro (unless freshly dissociated from the nerve), in association with unmyelinated axons in the adult, or in association with pre-myelinated axons in development. Since myelination involves large increase in membrane surface area (Webster, 1971), it might be argued that here is a quantitative problem in detecting $P_{0}$ before this increase. This is unlikely because myelination is only just beginning in the neonatal sciatic nerve, yet all 


\section{Table I. Summary of $P_{0}$ assays on various rat tissues and cultured cells}

(Immunofluorescence assays were performed on prefixed cells or frozen sections, as described (Brockes et al. 1980a; Mirsky et al. 1980). Immuno-autoradiography assays were performed on SDS-polyacrylamide gels, by staining with anti-Po and [12I]Staphylococcus aureus protein A (Brockes et al. I $980 a$ ). The results are stated in terms of the molecular weight, in thousands of daltons, of the positively reacting species, if any. The $\mathrm{P}_{0}$ radioimmunoassay uses competition between solid-phase antigen and the unknown, soluble antigen for anti-P $P_{0}$ binding, followed by [ $\left.{ }^{12} \mathrm{I}\right]$ protein $A$ to detect the bound antibody. The results are stated as mean \pm standard deviation of determinants on 2-4 samples. For details see Fryxell et al. (198I). All three assays used the same batch of rabbit anti-Po (Brockes et al. 1980a). Schwann cells were derived from rat sciatic nerve, as described (Brockes et al. 1979).)

\begin{tabular}{|c|c|c|c|}
\hline Sample & $\begin{array}{l}\text { Immuno- } \\
\text { fluorescence }\end{array}$ & $\begin{array}{c}\text { Immuno- } \\
\text { autoradiography }\end{array}$ & $\begin{array}{c}\mathrm{P}_{0} \text { radio- } \\
\text { immunoassay } \\
\left(\mu_{\mathrm{g}} \mathrm{P}_{0} / \mathrm{mg} \text { total }\right. \\
\text { protein })\end{array}$ \\
\hline $\begin{array}{l}\text { nerve } \\
\text { I \&-day) sciatic nerve } \\
\text { l sympathetic trunk }\end{array}$ & $\begin{array}{c}+++ \\
\text { Focal }++ \\
\text { Focal }++ \\
-\end{array}$ & $\begin{array}{l}28 \mathrm{~K} \mathrm{P} \mathrm{P}_{0}^{\circ} \\
28 \mathrm{~K} \mathrm{P}_{0} \\
\text { nd } \\
\text { nd }\end{array}$ & $\begin{array}{l}87 \pm 7 \\
I \cdot 8 \pm 1 \cdot 1 \\
\text { nd } \\
0.2 \pm 0.004\end{array}$ \\
\hline yelin & $\begin{array}{l}\text { N/A } \\
\text { N/A }\end{array}$ & ${ }_{-}^{28 K} \mathrm{P}_{0}$ & $\begin{array}{c}640 \dagger \\
0.3 \pm 0.02\end{array}$ \\
\hline Is, $\ddagger$ cultured < I day & $\begin{array}{r}49 \pm 11 \% \\
\text { positive } \$\end{array}$ & nd & $3 \cdot 7 \pm 1 \cdot 3$ \\
\hline $\begin{array}{l}\mid s, \| \text { cultured }>4 \text { days } \\
l s, \| \text { cultured }>4 \text { days, }\end{array}$ & $\overrightarrow{\mathrm{N} / \mathrm{A}}$ & - & $\begin{array}{l}0.3 \pm 0.2 \\
0.5 \pm 0.2\end{array}$ \\
\hline
\end{tabular}

Adult sciatic nerve

Neonatal (o-I -day) sciatic nerve

Adult cervical sympathetic trunk

Adult brain

Peripheral myelin

Central myelin

Schwann cells, $\ddagger$ cultured $<$ I day

Schwann cells, $\|$ cultured $>4$ days

Schwann cells, $\|$ cultured $>4$ days, membrane preparation fluorescence

$$
\begin{gathered}
+++ \\
\text { Focal }++ \\
\text { Focal }++ \\
- \\
\text { N/A } \\
\text { N/A } \\
49 \pm 11 \% \\
\text { positive } \\
- \\
\text { N/A }
\end{gathered}
$$

N/A, Not applicable; nd, not done; - , negative.

- Immunoautoradiography in these two cases revealed reaction with a lower-molecular-weight band, present in minor amounts compared to the $28 \mathrm{~K}$ species (see Brockes et al. $1980 a$ ). It may be a breakdown product of $P_{0}$.

† Data from Greenfield et al. (1973). This is based on densitometry of gels of peripheral myelin proteins, which we also use to measure the $P_{0}$ in our standard competitor solutions (peripheral myelin extracts). Thus measurement of the $P_{0}$ content of peripheral myelin by RIA would not provide any new information.

I Schwann cells from 4 - to 7-day rats.

\$ Data from Mirsky et al. (1980).

|| Schwann cells from neonatal rats.

three assays can detect $P_{0}$ in this tissue. More to the point, the level in the Schwanncell membrane has been shown by RIA to be at least rooo-fold lower than that in the myelin membrane (Fryxell et al. 198I). We have recently found that cultured Schwann cells, which have undetectable levels of $P_{0}$, are competent to be induced to make $P_{0}$ when confronted with axons of rat dorsal root ganglion neurones in vitro (K. J.F. \& J.P.B., unpublished observations). The rapid loss of detectable levels of $P_{0}$ and of myelin basic protein in cultured Schwann cells after dissociation (Mirsky et al. 1980) suggests that a continuing signal is required from the nerve in order to maintain their expression.

Interestingly, oligodendrocytes appear to regulate several myelin components, including myelin basic protein, differently from Schwann cells. Oligodendrocytes in dissociated cultures of neonatal optic nerve, corpus callosum or cerebellum continue to express galactosylceramide, sulfatide and myelin basic protein for many weeks in the absence of neurones. Galactosylceramide and sulphatide, its sulphate ester are 'myelin-typical' glycolipids which are found in the myelin membrane in hig. 
- vels, but are not confined to it (Norton, 1977). Freshly dissociated Schwann cells are positive for these lipids by immunofluorescence, but they all become negative after 5-7 days in culture (Mirsky et al. 1980).

Although these observations are of great interest and indicate a clear difference between the peripheral and central myelin forming cells, it will in the future be important to obtain more quantitative estimates of the expression of myelin components. Although sulphatide was not detectable after immunofluorescence assays on Schwann cells cultured for $>7$ days, it was detectable after biosynthetic labelling of the cells with ${ }^{25} \mathrm{SO}_{4}{ }^{2-}$ and purification of lipids (Fryxell, 1980). Schwann cells that had been maintained in culture for at least 14 days incorporated at least 50 -fold more radioactivity into lipids (per mg protein) than did fibroblasts. Almost all of the $\left.{ }^{[3} \mathrm{S}\right]$-sulfolipids were sulphatide as shown by thin-layer chromatography on two independent solvent systems, with standard and unknown run in the same track (Fryxell, 1980). It is certainly possible that interaction with the nerve increases the level of sulphatide in the Schwann-cell membrane, as suggested by the immunofluorescence assays. Nevertheless, a continuing interaction with the nerve is not strictly necessary for sulphatide synthesis by Schwann cells. It is possible that Schwann cells do continue to synthesize $P_{0}$ at lower levels than we have been able to detect, in which case the regulation of $P_{0}$ may not differ from that of sulphatide. It will require more detailed studies to determine if the difference between Schwann cells and oligodendrocytes in the regulation of the synthesis of myelin components is quantitative or qualitative. It is interesting to speculate, however, that since oligodendrocytes do not appear to systematically wrap unmyelinated central axons, oligodendrocytes may in some sense be committed to form myelin while Schwann cells are not.

In principle, there could be several different signals from the myelinated type of axon to the Schwann cell but we are concentrating on that responsible for the induction of $P_{0}$. This is because the appearance of $P_{0}$, as detected by the RIA, is such a sensitive and specific index of the neurone-glial interaction. We are currently attempting to derive antisera to the surface of neurones or Schwann cells that block induction of $P_{0}$ in the in vitro system with DRG neurones, as well as investigating the effect of neuronal membrane fractions on the level of $P_{0}$ in cultured Schwann cells. Any insights into the molecules, of either cell type, that mediate this interaction would obviously be of great interest.

THE CONTROL OF SCHWANN-CELL PROLIFERATION IN FITRO

The control of cell division is a most important aspect of development in the nervous system, and of the responses involved on wounding and in regeneration. This section of the paper will consider a very interesting example of neurone-glia interactions - the ability of the neurone to act as a source of mitogen for the glial cell (see review in Brockes \& Lemke, I981). To briefly summarize glial cell division in vivo: glia divide during development, are relatively quiescent in the mature animal, and may divide during wounding and regeneration. It is very difficult from in vivo observations alone, however, to analyse the molecular or even the cellular Dis for the control of mitosis. Studies in vitro have been essential both for defining 


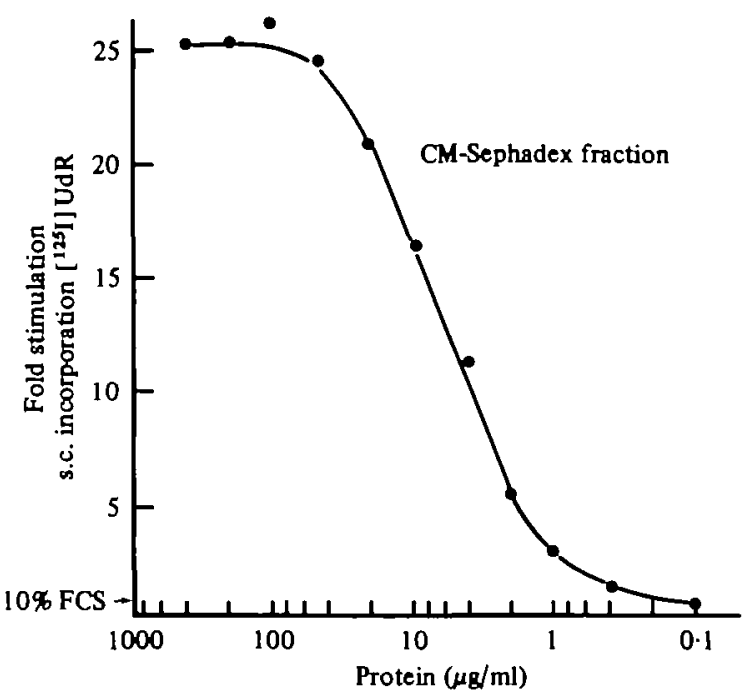

Fig. 5. Stimulation of [ $\left.{ }^{28} \mathrm{I}\right] \mathrm{iod}$ dedexyuridine incorporation into Schwann cells by partially purified extracts of the bovine pituitary. Purified Schwann cells were grown for $48 \mathrm{~h}$ in microwells in the presence of $10 \%$ foetal calf serum and various concentrations of pituitary extract fractionated on CM sephadex according to Gospodarowicz (1975). The cells were labelled with [ $\left.{ }^{12} \mathrm{I}\right] \mathrm{IUdR}$ for the final $\mathrm{I} 8 \mathrm{~h}$ and the incorporation of radioactivity was determined (see Brockes et al. I $980 b$ for details). Stimulation plateaus at approximately 25 -fold in this experiment, and is linear with log protein concentration over most of the range.

some of the cellular interactions that are involved, and for setting up assays to guide purification of the molecules that underly them.

One body of work has provided evidence for the existence of a mitogen for Schwann cells on the surface of neurites of cultured sensory (Wood \& Bunge, 1975; Wood, I 976; Salzer \& Bunge, 1980; Salzer et al. 1980a; Salzer, Bunge \& Glaser, 1980b) and sympathetic (McCarthy \& Partlow, 1976; Hanson \& Partlow, I980) ganglion cells. This analysis has depended on methods for obtaining purified populations of neurons and of non-neuronal (Schwann and satellite) cells by use of antimotic agents (Wood, I976) or selective adhesion (McCarthy \& Partlow, 1976). When the purified populations were mixed, there was a stimulation of DNA synthesis in the non-neuronal population as assayed by radioactive thymidine incorporation (McCarthy \& Partlow, 1976) or autoradiography (Wood \& Bunge, 1975). This interaction appears, by several lines of evidence, to depend on contact between the cells. For example, if rat sensory neurites and rat Schwann cells were separated by a collagen diaphragm $6 \mu \mathrm{m}$ thick, Schwann-cell proliferation was prevented (Salzer et al. 1980a). It has also been possible to demonstrate that an isolated membrane fraction from the neurites, but not a soluble fraction, was competent to stimulate the Schwann cells (Salzer et al. 1980b). Although there is no direct evidence for the importance of this surface mitogen in vivo, it is consistent with evidence that the full complement of axons is required to generate the normal number of Schwann cells (see, for example, Aguayo et al. 1976c). It should be most interesting to purify and characterize the neurite mitogen, and to investigate its role in the control of Schwann cell division in vivo. 
An alternative approach, which has been generally productive in the study of cell proliferation, is the study of soluble growth factors. The growth and division of animal cells in culture requires the presence of growth factors and hormones that are normally supplied in serum. For certain cell types, it has been possible to replace the serum requirement with an appropriate mixture of growth factors and hormones (Bottenstein et al. 1979), and the use of such defined media is becoming increasingly important in cell biology. Furthermore, it has been suggested that the definition of the requirements for a particular cell type may allow the isolation of novel molecules of biological significance (Ross \& Sato, 1979). The ability to reproducibly obtain highly purified populations of Schwann cells has allowed us to investigate a new component of the brain and pituitary that stimulates their proliferation. While the significance of this component is still far from clear, our studies to this point do suggest that it will be of interest.

As mentioned earlier, the purified rat Schwann cells divide very slowly in a conventional tissue culture medium containing $10 \%$ foetal serum. They are stimulated to synthesize DNA and divide by a factor present in extracts of bovine brain and pituitary (Raff et al. 1978b; Brockes et al. 1979). The most convenient assay for this activity has been to measure the incorporation of $\left[{ }^{125} \mathrm{I}\right]$ iododeoxyuridine into the DNA of Schwann cells growing in microwells (Raff et al. 1978a,b). While the background proliferation may vary with different batches of Schwann cells, there is generally a 20 - to 100 -fold stimulation of $\left[{ }^{186} \mathrm{I}\right] \mathrm{UdR}$ incorporation by partially purified preparations. Fig. 5 illustrates the microwell assay, and the linear dependence of stimulation on the logarithm of protein concentration over most of the range. In a preliminary study with crude extracts of various tissues, the activity was only detectable in the brain and pituitary, although peripheral nerve was uncertain because of inhibitory activity at some concentrations (Raff. et al. 1978b). Activity was not detectable in the non-neural tissues investigated. Furthermore, a variety of purified anterior and posterior lobe hormones and other growth factors were not effective at stimulating IUdR incorporation into the Schwann cells. Finally, the activity was destroyed by proteolytic digestion or boiling. It is important to emphasize that these studies depend on the very high purity of cell populations resulting from treatment with anti Thy-I and complement. The presence of even $I-5 \%$ contaminating fibroblasts would make it difficult to do decisive experiments.

We have recently purified the activity over 4000 -fold from a pool of $10 \mathrm{~kg}$ of frozen bovine pituitaries and 4000 lyophilized anterior lobes (the activity in anterior and posterior lobes is comparable) (Brockes, Lemke \& Balzer, $1980 b$; Lemke et al. 1980). The activity resides in a basic protein with a native molecular weight on gel filtration of approximately $6 \times 10^{4}$, and with a subunit molecular weight of $3 \times 10^{4}$. This component was obtained in approximately $30 \%$ purity and could be demonstrated to carry the activity by native gel electrophoresis at $\mathrm{pH} 4 \cdot 5$. The concentration required to give plateau stimulation is, when corrected for purity and molecular weight, comparable to that required for epidermal growth factor on fibroblast cell lines (see Brockes \& Lemke, I98I). The effect of the purified factor on cell division in cultured Schwann cells is illustrated in Fig. 6. As shown in Fig. 6(a), cells maintained in medium with the factor had a doubling time of approximately $30 \mathrm{~h}$. 


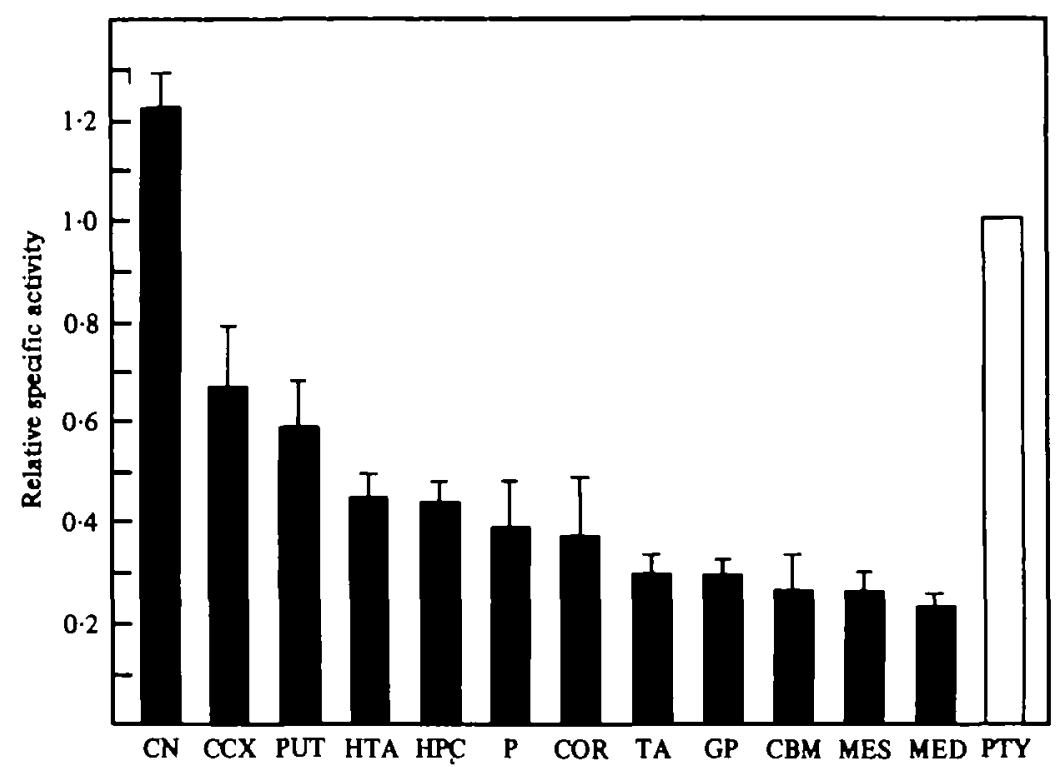

Fig. 7. Regional distribution of glial growth factor activity in the bovine brain. The activity of extracts of various areas was determined by dose-response curves (four points each) on the same batch of Schwann cells. The dose-response curves for different areas were approximately parallel. The activity is expressed relative to that in the pituitary at an extract concentration of $0.2 \mathrm{mg} / \mathrm{ml}$, i.e.

\section{$\frac{\text { fold stimulation of extract at } 0.2 \mathrm{mg} / \mathrm{ml}}{\text { fold stimulation of pituitary extract at } 0.2 \mathrm{mg} / \mathrm{ml} \text {. }}$}

The values are given as mean \pm s.D. for analyses performed on four separate brains. $\mathrm{CN}=$ caudate nucleus; $\mathrm{CCX}=$ cingulate cortex; $\mathrm{PUT}=$ putamen; $\mathrm{HTA}=$ hypothalamus; $\mathrm{HPC}=$ hippocampus; $\mathrm{P}=$ pons; $\mathrm{COR}=$ cerebral cortex; $\mathrm{TA}=$ thalamus; $\mathrm{GP}=$ globus pallidus; $\mathrm{CBM}=$ cerebellum; MES $=$ mesencephalon; $\mathrm{MED}=$ medulla $;$ and $\mathrm{PTY}=$ pituitary.

Photomicrographs of cells in the presence and absence of factor are shown in Fig. $6(b, c)$.

We have recently investigated the distribution of the activity in bovine brain (Lemke et al. 1980; Brockes, I981). As shown in Fig. 7, the activity is detectable in all areas examined but shows a 6 - to ro-fold variation in specific activity between regions. One area, the caudate nucleus, yields extracts of an even higher specific activity than the pituitary. Although the significance of this localization is unknown, the regional variation in activity does tend to suggest that the activity is a component of nerve cells. This is a point that we are now attempting to answer with immunohistochemical methods. The partially purified caudate and pituitary activities were indistinguishable when analyzed by ion exchange chromatography and native gel electrophoresis (Brockes \& Lemke, I981).

The presence of the activity in brain raises the question of its action on central glial cells. When the purified pituitary activity was added to dissociated cultures of the rat corpus callosum, the astrocytes were stimulated to take up radioactive thymidine, whereas the oligodendrocytes and 'macrophage-like' microglia were not 

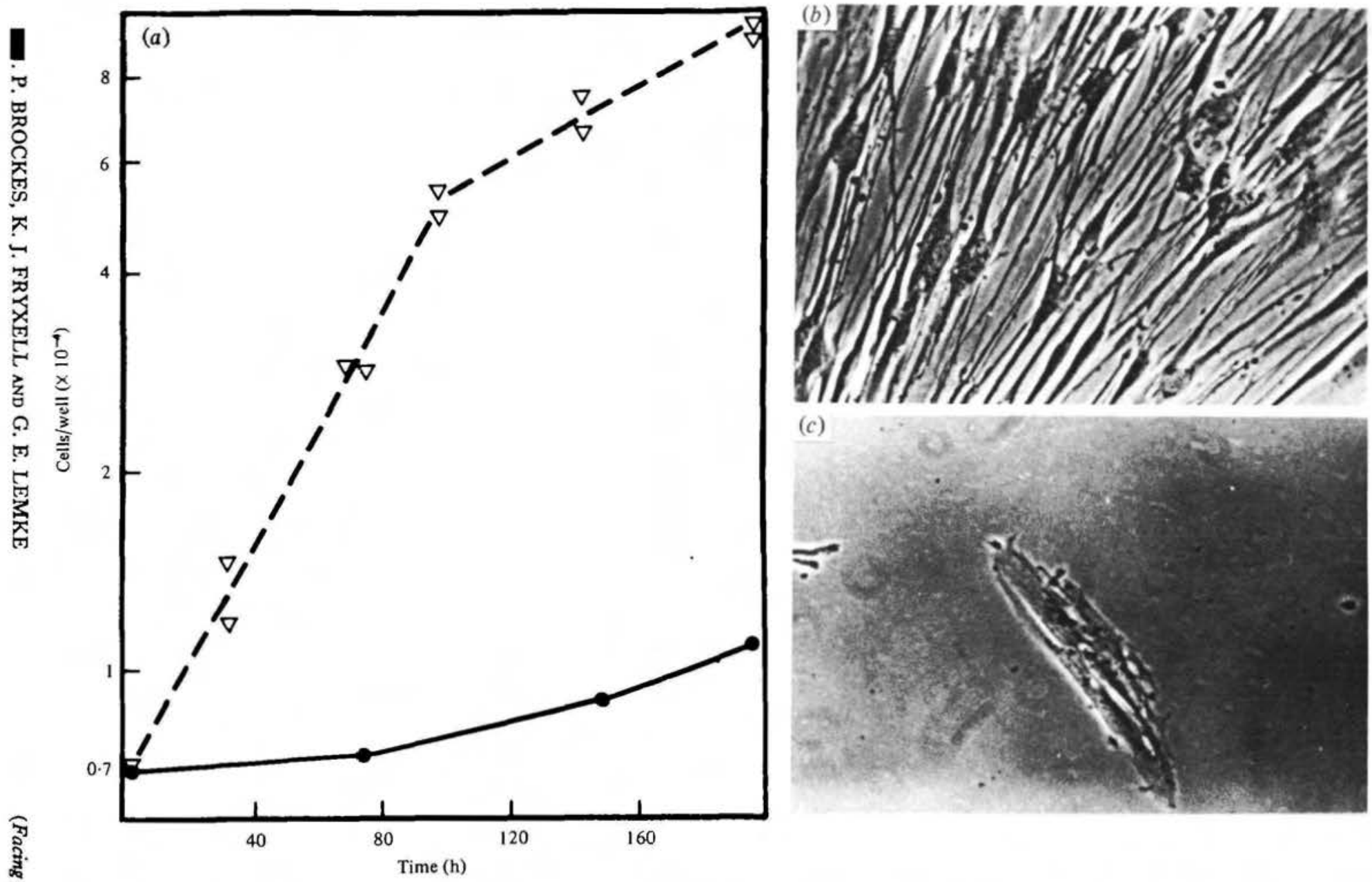

(c)



Fig. 6. Effect of the purificd pituitary factor on Schwann-cell proliferation. (a) Schwann cells were cultured in wells in medium with $10 \%$, foetal calf serum alone ( or with $2 \mu \mathrm{g} / \mathrm{ml}$ phosphocellulose fraction (Brockes et al. $1980 \mathrm{~b}$ ). The number of cells per well was determined at various times ufter plating. (b) Phase-contrast photomicrograph of cells from the experiment of $(a)$ that had been in factor for 5 days. (c) A parallel group of cells from a culture maintaned in the absence of factor. 



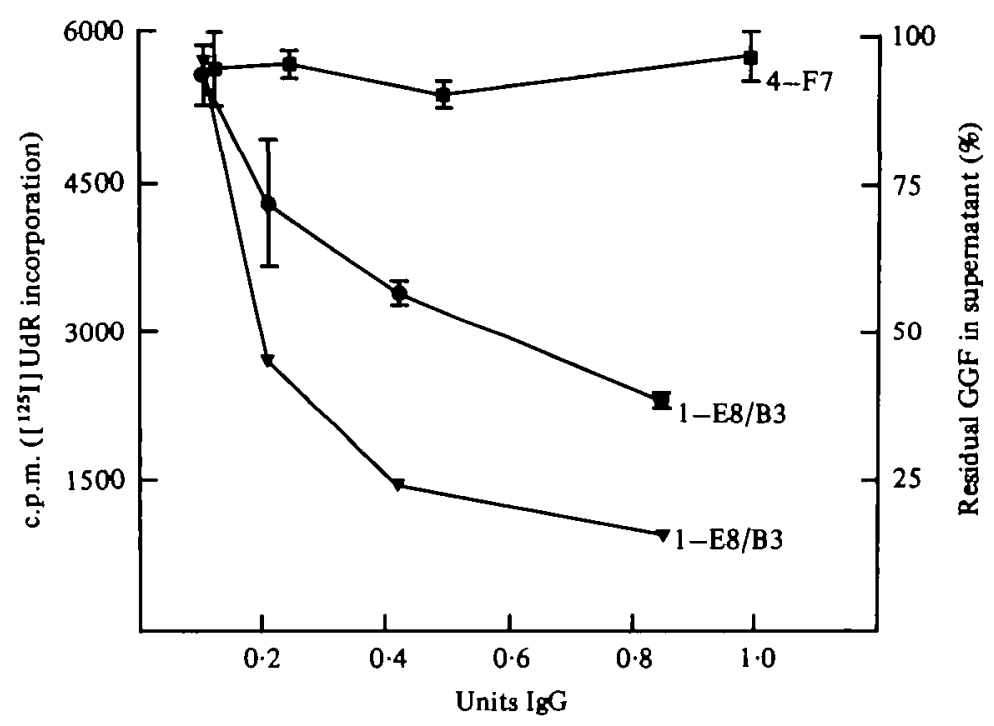

Fig. 8. Titration of monoclonal anti GGF. $4-F_{7}$ is a clone secreting IgG that does not react with GGF, whereas $1-E 8 / B_{3}$ does. Verying amounts of culture supernatant were incubated with the CM cellulose fraction (Brockes et al. i $980 b$ ) of GGF for $30 \mathrm{~min}$ at $37^{\circ} \mathrm{C}$. Carrier mouse $I_{g} G$ and purified rabbit anti-mouse $I_{g} G$ were added and incubated overnight at $4{ }^{\circ} \mathrm{C}$. After centrifugation for $4 \mathrm{~min}$ at $20000 \mathrm{~g}$ the supernatant was assayed for its ability to stimulate $18 \mathrm{I}-\mathrm{IUdR}$ incorporation into Schwann cells in microwells. The decrease in stimulation by $\mathrm{E} 8 / \mathrm{B}_{3}$ is corrected by the logarithmic dosage relationship (see Fig. 5) to give the amount of factor protein remaining in the supernatant $(\nabla)$. One unit of $\operatorname{IgG}$ is the amount in $4 \circ \mu \mathrm{l}$ of $\mathrm{F}_{7}$ culture supernatant as determined with a quantitative ELISA assay. The values for $\mathrm{I}-\mathrm{E} 8 / \mathrm{B}_{3}$ are normalized to this. Each point is mean \pm S.D. of three microwell assays.

detectably stimulated (Brockes et al. $1980 b$ ). In each case the glial cells were identified with fluorescent antibodies which were cell type specific (Raff et al. 1979). The activities against astrocytes and Schwann cells migrated together on gel electrophoresis, providing strong evidence that the same molecule acts on both cell types. A similar analysis indicates that this molecule also acts on rat muscle fibroblasts, a non-neural cell type (Brockes \& Lemke, I98I). In view of its manner of derivation, and localization, the component has been tentatively named Glial Growth Factor (GGF).

The role of this factor in neurone-glial interactions is not known at this time. It might be continually released from the pituitary into the circulation as a circulating growth factor, or as a specific hormonal signal under particular circumstances. An obvious possibility is that it may be important in the brain as a signal for astrocyte proliferation during development or after injury. We have also speculated (Brockes \& Lemke, 198I) that it may be important as a neutrotrophic factor in circumstances of nerve stimulated mitosis such as amphibian limb regeneration.

Our ability to purify the molecule to homogeneity, to investigate its distribution, and to evaluate the various possibilities for its functional role has recently been advanced by the derivation of a set of monoclonal antibodies (Lemke \& Brockes, 981). After immunizing with side fractions of the partially purified pituitary factor, 
spleen cells were fused with the NS-I myeloma and cloned by standard procedures! The ability of a positive clone to bind to GGF in relatively impure preparations is illustrated in Fig. 8. After removal of immune complexes with antibody to mouse IgG, the supernatant is specifically depleted of GGF activity on Schwann cells. These reagents are currently being used in attempts to further purify GGF and determine its cellular localization.

\section{CONCLUSION}

The use of immunological methods to identify and purify distinct populations of neurones and glia promises to becoming increasingly important as more specific monoclonal reagents become available. We have tried to illustrate the utility of this approach by reference to our recent studies on the Schwann cell. The availability of purified populations in vitro aided in the decisive evaluation of the issue of myelin protein induction, as well as the establishment of in vitro systems that should allow the future characterization of the molecules involved in myelin induction. Another benefit has been the definition of a new growth factor, probably a component of nerve cells in the brain and pituitary, which stimulates the division of several cell types. We hope that study of both issues will contribute to our knowledge of the molecular basis of neurone-glial interactions.

We thank D. R. Balzer Jr. and T. Stevens for their skilful assistance, and Dr K. Stygall for her help in the derivation of monoclonal antibodies to GGF. Research at the California Institute of Technology was supported by grants from the Pew Memorial Trust and the Kroc Foundation, by NIH grant ROI NS I 4403 and by Biomedical Research Support grant RR o7003.

\section{REFERENCES}

Aguayo, A. J., Epps, J., Charron, L. \& Bray, G. M. (1976a). Multipotentiality of Schwann cells in cross-anastomosed and grafted myelinated and unmyelinated nerves: Quantitative microscopy and radioautography. Brain Res. 104, 1-20.

Aguayo, A. J., Charron, L. \& Bray, G. M. (I976b). Potential of Schwann cells from unmyelinated nerves to produce myelin: A quantitive ultrastructural and autoradiographic study. $\mathcal{F}$. Neurocytol 5, 565-573.

Aguayo, A. J., Peyronnard, J. M., Terry, L. C., Romine, J. S. \& Bray, G. M. (i976c). Neonatal neuronal loss in rat superior cervical ganglia: Retrograde effects on developing preganglionic axons and Schwann cells. $\mathcal{F}$. Neurocytol. 5, $137-155$.

Bottenstein, J., Hayashi, I., Hutchings, S., Masui, H., Mather, J., McClure, D. B., Ohasa, S., Rizzino, A., Sato, G., Serrero, G., Wolfe, R. \& WU, R. (1979). The growth of cells in serumfree hormone-supplemented media. Meth. Enzym. 58, 94-rog.

Brockes, J. P., Fields, K. L. \& RAFF, M. C. (I 977). A surface antigenic marker for rat Schwann cells. Nature, Lond. 266, 364-366.

Brockes, J. P., Fields, K. L. \& RafF, M. C. (1979). Studies on cultured rat Schwann cells. I. Establishment of purified populations from cultures of peripheral nerve. Brain Res. 165, 105-1 8.

Brockes, J. P. \& RAFf, M. C. (1979). Studies on cultured rat Schwann cells. II. Comparison with a rat Schwann cell line. In vitro $15,772-778$.

Brockes, J. P., Raff, M. C., Nischiguchi, D. J. \& Winter, J. (ig80a). Studies on cultured rat Schwann cells. III. Assays for peripheral myelin proteins. $\mathcal{F}$. Neurocytol. 9, 67-77.

Brockes, J. P., Lemke, G. E. \& Balzer, D. R. JR. (1980b). Purification and preliminary characterization of a glial growth factor from the bovine pituitary. $\mathscr{F}$. Biol. Chem. 255, 8374-8377.

BRockes, J. P. (198I). Identification and purification of cultured Schwann cells, and a purified factor 
controlling their proliferation. In Proc. First Int. Conf. Spinal Chord Reconstruction (ed. C. C. Ko). Raven Preas. (In the Press.)

Brockss, J. P. \& Lemke, G. E. (1981). The neuron as a source of mitogen; its influence on the proliferation of neural and non-neural cells. In Development in the Nervous System (ed. J. D. Feldman and D. R. Garrod). Cambridge University Press. (In the Press.)

BURRIDGE, K. (1980). Direct identification of specific glycoproteins and antigens in sodium dodecyl sulfate gels. In Meth. Enzym. 50, 54-64.

DOUglas, T. C. (1972). Occurrence of a theta-like antigen in rats. $\%$. exp. Med. 136, 1054-1062.

DunCaN, D. (1934). A relation between axon diameter and myelination determined by measurements of myelinated spinal root fibers. F. comp. Newrol. 60, 437-471.

Everly, J. L., Brady, R. O. \& Quarles, R. H. (1974). Evidence that the major protein in rat sciatic nerve myelin is a glycoprotein. J. Neuro. Chem. 21, 329-334.

Figlds, K. L., Gosling, C., Megson, M. \& Stern, P. L. (1975). New cell surface antigens in rat defined by tumors of the nervous system. Prac. natn. Acad. Sci. U.S.A. 72, I 296-1 300.

Fields, K. L., Brockes, J. P., Mirsky, R. \& Wendon, L. N. B. (1978). Cell surface markers for distinguishing different types of rat dorsal root ganglion cells in culture. Cell 14, 43-5 I.

Fribdlander, M. (ed.) ( 1979 ). Immunological approaches to embryonic development and differentiation. Curr. Top. Dev. Biol. 13. New York: Academic Press.

FrYXELL, K. J. (1980). Synthesis of sulfatide by cultured rat Schwann cells. $\mathcal{~}$. Newrochem. 35, I $461-$ 1464 .

Fryxbll, K. J., Balzer, D. R. Jr. \& Brockes, J. P. (I98I). A solid phase radioimmunoassay for the $P_{0}$ protein of peripheral myelin. (Submitted for publication.)

Geren, B. B. (1954). The formation from the Schwann cell surface of the myelin in the peripheral nerves of chick embryos. Expl Cell Res. 7, 558-562.

Gospodarowicz, D. (1975). Purification of a fibroblast growth factor from bovine pituitary. \%. biol. Chem. 250, 25 I 5-2520.

Greenfield, S., Brostoff, S., Eylar, E. H. \& Morell, P. (1973). Protein composition of myelin of the peripheral nervous system. F. Neurochem. 20, 1 207-1216.

Hanson, G. R. \& Partlow, L. M. (1980). A comparigon of two factors affecting the proliferation of non-neuronal (glial) cells in vitro. Brain Res. 192, 371-381.

Hillarp, N. A. \& Olivechona, H. (1946). The role played by the axon and the Schwann cells in the degree of myelination of the peripheral nerve fiber. Acta. anat. (Basel) 2, 17-32.

Lemke, G. E., Balzer, D. R. JR., Stygall, K. A. \& Brockes, J. P. (1980). Glial growth factor: a new component of the brain and pituitary. Soc. Neurosci. Abst. 6, 329.

LEMKE, G. E. \& Brockes, J. P. (198I). An immunochemical approach to the purification and characterization of glial growth factor. In Monoclonal Antibodies Against Neural Antigens (ed. L. Reichardt, M. C. Raff and R. McKay). Cold Spring Harbor Laboratory. (In the Press.)

Lesley, J. F. \& LenNon, V. A. (1977). Transitory expression of Thy-1 antigen in skeleton muscle development. Nature, Lond. 268, 163-165.

MatThews, M. A. (1968). An electronmicroscopic study of the relationship between axon diameter and the initiation of myelin production in the peripheral nervous system. Anat. Rec. 101, 337351 .

McCarthy, K. D. \& Partlow, L. M. (1976). Preparation of pure neuronal and non-neuronal cultures from embryonic chick sympathetic ganglia; a new method based on both differential cell adhesiveness and the formation of homotypic neuronal aggregates. Brain Res. 114, 391-414.

Mirsky, R., Winter, J., Abney, E. R., Pruss, R. M., Gavrilovic, J. \& Raff, M. C. (1980). Myelinspecific proteins and glycolipids in rat Schwann cells and oligodendrocytes in culture. $\%$. Cell Biol. 84, $483-494$.

Mischel, B. B. \& Shiror, S. M. (eds.) (1980). Selected Methods in Cellular Immunology. San Francisco: W. H. Freeman.

Norton, W. T. (1977). Isolation and characterization of myelin. In Myelin (P. Morell, ed.), pp. I6r199. Plenum Press, New York.

PfEIfFer, S. E. \& WeChsleq, W. (1972). Biochemically differentiated neoplastic clone of Schwann cells. Proc. natn. Acad. Sci. U.S.A. 69, 2885-2889.

Pfaiffer, S. E., Betschart, B., Cook, J., Mancini, P. \& Morris, R. (1978). Glial cell lines. In Cell Tissue and Organ Cultures in Neurobiology (ed. S. Fedoroff and L. Hertz), pp. 287-346. New York: Academic Press.

RAFF, M. C. (1969). Theta isoantigen as a marker of thymus-derived lymphocytes in mice. Nature, Lond. 224, 378-380.

RafF, M. C., Hornby-Smith, A. \& Brockes, J. P. (1978a). Cyclic AMP as a mitogenic signal for cultured rat Schwann cells. Nature, Lond. 273, 672-673.

Raff, M. C., ABNeY, E. R., Brockes, J. P. \& HoRNBY-Smith, A. (1978b). Schwann cell growth factors.

Cell ${ }_{55}, 813-822$. 
Raff, M. C., Fields, K. L., Hakomori, S. L., Mirsky, R., Pruss, R. M. \& Winter, J. (i979). Cep type specific markers for distinguishing and studying neurons and the major classes of glial cells in culture. Brain Res. 174, 283-308.

Reichardt, L., Raff, M. C. \& McKay, R. (198I). Monoclonal Antibodies Against Neural Antigens. Cold Spring Harbor Laboratory Press. (In the Press.)

Reif, A. E. \& Allen, J. M. V. (I 966). Mouse thymic isoantigens. Nature, Lond. 209, 52 I-523.

Ross, R. \& Sato, G. H. (1979). In Hormones and Cell Culture, vol. B (ed. R. Ross and G. H. Sato), pp. 965-97I. Cold Spring Harbor Laboratory.

Salzer, J. L. \& Bunge, R. P. (1980). Studies of Schwann cell proliferation. I. An analysis in tissue culture of proliferation during development, Wallerian degeneration, and direct injury. $\%$. Cell Biol. 84, 739-752.

Salzer, J. L., Bunge, R. P. \& Glazer, L. (1980b). Studies of Schwann cell proliferation. III. Evidence for the surface localization of the neurite mitogen. J. Cell Biol. 84, 767-778.

Salzer, J. L., Williams, A. K., Glaser, L. \& Bunge, R. P. (1980a). Studies of Schwann cell proliferation. II. Characterization of the stimulation and specificity of the response to a neurite membrane fraction. \%. Cell Biol. 84, 753-766.

Scheid, M., Boyse, E. A., Carsweil, E. A. \& OLd, L. J. (1972). Serologically demonstrable alloantigens of mouse epidermal cells. \%. exp. Med. 135, 938-955.

Simpson, S. A. \& Young, J. Z. (1945). Regeneration of fiber diameter after cross-unions of visceral and somatic nerves. F. Anat., Lond. 79, 48-65.

Spencer, P. S. \& Weinberg, H. J. (1978). Axonal specification of Schwann cell expression and myelination. In Physiology and Pathobiology of Axons (ed. S. G. Waxman). New York: Raven Press.

STRRN, P. L. (1973). Theta alloantigen on mouse and rat fibroblasta. Nature, new Biol. 246, 76-78.

Trapp, B. D., McIntYre, L. J., Quarles, R. H., Sterngerghr, N. H. \& Webster, H. de F. (1979). Immunocytochemical localization of rat peripheral nervous system myelin proteins: $\mathrm{P}_{2}$ protein is not a component of all peripheral nervous system myelin sheaths. Proc. natn. Acad. Sci. U.S.A. 76, $3552-3556$.

WEBsteR, H. DE F. (197I). The geometry of peripheral myelin sheaths during their formation and growth in rat sciatic nerves. $\%$. Cell Bial. 48, 348-367.

WERBTER, H. DR F. (1975). Development of peripheral myelinated and unmyelinated nerve fibers. In Peripheral Neuropathy, vol. I (ed. P. J. Dyck, P. K. Thomas and E. H. Lambert), pp. 37-61. Philadelphia: W. B. Saunders.

Weinberg, H. J. \& Spenchi, P. S. (1976). Studies on the control of myelinogenegis. II. Evidence for neuronal regulation of myelin production. Brain Res. II3, 363-378.

Wood, J. G. \& DAwson, R. M. C. (1974). Some properties of a major structural glycoprotein of sciatic nerve. $\mathcal{Y}$. Neurachem. 22, 631-635.

Wood, P. M. \& BUNGe, R. P. (1975). Evidence that sensory axons are mitogenic for Schwann cells. Nature, Lond. 256, 66 $\mathrm{I}-664$.

Wood, P. (1976). Separation of functional Schwann cells and neurons from peripheral nerve tissue. Brain Res. 115, 361-375. 